\title{
Selenide Chitosan Sulfate Improved The Hepatocyte Activity, Growth Performance, and Anti-Oxidation Ability by Activating The Thioredoxin Reductase of Chickens In Vitro and In Vivo
}

\section{Lele Hou}

Qingdao Agriculture University: Qingdao Agricultural University

Huiling Qiu

Qingdao Agriculture University: Qingdao Agricultural University

Lianqin Zhu

Qingdao Agriculture University: Qingdao Agricultural University

Yufeng Huang

Qingdao Agriculture University: Qingdao Agricultural University

Shansong Gao

Qingdao Agriculture University: Qingdao Agricultural University

Fu Chen ( $\nabla$ cf507@sohu.com )

Qingdao Agriculture University: Qingdao Agricultural University

\section{Research}

Keywords: LS-COS-Se, TrxR, hepatocyte, chickens

Posted Date: September 21st, 2020

DOI: https://doi.org/10.21203/rs.3.rs-76175/v1

License: (c) (i) This work is licensed under a Creative Commons Attribution 4.0 International License.

Read Full License 
Selenide chitosan sulfate improved the hepatocyte activity, growth performance, and anti-oxidation ability by activating the thioredoxin reductase of chickens in vitro and in vivo Lele $\mathrm{Hou}^{1 \dagger}$, Huiling $\mathrm{Qiu}^{2 \dagger}$, Lianqin Zhu ${ }^{1}$, Yufeng Huang ${ }^{1}$, Shansong Gao ${ }^{1}$, Fu Chen ${ }^{1 *}$

*Correspondence: F. Chen: cf507@sohu.com;

${ }^{\dagger}$ Lele Hou and Huiling Qiu contributed equally to this work.

${ }^{1}$ Institute of Animal Nutritional Metabolic Disease and Poisoning Disease, College of Veterinary Medicine, Qingdao Agricultural University, Qingdao, 266109, China;

${ }^{2}$ Haidu College, Qingdao Agricultural University, Laiyang, 265200, China; 


\begin{abstract}
Background: There are very few studies on the synergy effects of biological antioxidant activity on selenium (Se) and sulfate. This study evaluated the effect of selenide chitosan sulfate (LS-COS-Se) on the hepatocytes activity, growth performance, and anti-oxidation ability by activating the thioredoxin reductase (TrxR) system of specific pathogen free (SPF) chickens in vitro and in vivo.
\end{abstract}

Methods: The hepatocytes were obtained in vitro and a total of 240 SPF White Leghorns chickens ( 7 days of age and body weight of $45.0 \pm 2.0 \mathrm{~g}$ ) were collected in vivo. The hepatocytes and chickens were randomly allocated into six treatment groups: control group; chitosan (COS) group; sodium selenite $\left(\mathrm{Na}_{2} \mathrm{SeO}_{3}\right)$ group; selenide chitosan (COS-Se) group; chitosan sulfate (LS-COS) group; LS-COS-Se group. After $24 \mathrm{~h}$, the culture medium and hepatocytes were collected and preserved respectively for analyzing the metabolic activity of hepatocytes. Gowth performance was evaluated and chickens were euthanized to obtain plasma and liver tissue to measure antioxidant associated parameter on days 14 and 28 .

Results: The experiment in vitro showed that the activities of TrxR, superoxide dismutase (SOD), catalase (CAT) in culture medium and the levels of thioredoxin reductase 1 (TrxR-1) and thioredoxin reductase 3 (TrxR-3) mRNA in hepatocytes in LS-COS-Se group were significantly 
higher $(P<0.05)$, but the content of malondialdehyde (MDA) and the activity of lactate dehydrogenase (LDH) significantly decreased $(P<0.05)$ than those in control, COS and LS-COS groups. Compared with $\mathrm{Na}_{2} \mathrm{SeO}_{3}$ and COS-Se groups, the levels of TrxR-1 and TrxR-3 mRNA in hepatocytes and the activity of SOD in culture medium significantly increased in LS-COS-Se group $(P<0.05)$. The experiment in vivo showed that the baby weight on $14 \mathrm{~d}$ and $28 \mathrm{~d}$, the activities of TrxR, SOD and anti-superoxide anion radical $\left(\mathrm{AntiO}_{2}^{-}\right)$in plasma and the levels of TrxR-1 and TrxR-3 mRNA in liver of dietary supplementation with LS-COS-Se were significantly higher than those in control, COS and LS-COS groups $(P<0.05)$. The activities of TrxR and SOD in plasma of dietary supplementation with LS-COS-Se were significantly higher than those of $\mathrm{Na}_{2} \mathrm{SeO}_{3}$ group and COS-Se group $(P<0.05)$.

Conclusion: LS-COS-Se as potential antioxidant improved the hepatocytes activity, growth performance, and anti-oxidation ability by activating the TrxR system of SPF chickens in vitro and in vivo. The better biological activity of LS-COS-Se was mainly due to the synergistic effect of Se and sulfate on TrxR system.

Keywords: LS-COS-Se; TrxR; hepatocyte; chickens

\section{Introduction}

Selenium (Se) could catalyze hydrogen peroxide reduction, protect cell membrane and reduce oxidative damage [1]. It was a necessary 
micronutrient for health, growth, reproduction and immunity of humans and animals [2-7]. In a certain concentration range, with the increase of biological effects of selenium in the body, the concentration of reactive oxygen free radicals gradually decreases, which played an important role in the formation and defense of oxidative stress $[8,9]$. Chitosan (COS), was a kind of bioactive macromolecular compounds obtained by chemical or enzymatic hydrolysis of chitosan, was the only alkaline amino oligosaccharides in natural sugars. COS had many biological activities, such as low molecular weight, good dissolution, low viscosity, non-cytotoxicity, anti-cancer, anti-tumor, anti-inflammation, anti-oxidation, increasing calcium absorption [10-13]. It was easy to be absorbed, transformed and utilized in vivo by two or more ways such as carrier protein or free diffusion [14]. Chemical modification of COS can improve its solubility, enhance its biological effects and hold a lower toxicity [15]. COS was widely used in the fields of medicine, pharmacy, and animal husbandry $[14,16]$.

Selenide chitosan sulfate (LS-COS-Se) was the product of COS modified by selenization and sulfation. Chen et al. had shown the biological activity of Se-CTS-S that mainly benefited from the synergistic effects of Se and sulfate on glutathione system. But LS-COS-Se was unknown whether it could play the synergistic effect of Se and sulfate on thioredoxin reductase (TrxR) system. TrxR was a dimer selenase of 
NADPH oxidation pathway, which participates in the physiological processes of redox, cell proliferation and DNA synthesis. TrxR protected cells and tissues in the event of oxidative stress by maintaining the reductive state in cells [17].

The purpose of this experiment was to study the effect of LS-COS-Se on TrxR in vivo and in vitro to find the better biological activity for improving the growth performance and antioxidant capacity of chickens, and to compare it with sodium selenite $\left(\mathrm{Na}_{2} \mathrm{SeO}_{3}\right)$, chitosan (COS), selenide chitosan (COS-Se) and chitosan sulfate (LS-COS).

\section{Material and methods}

\section{Animals and experimental design}

All animal protocols used in this study were in accordance with the Guidelines for the Care and Use of Animals for Research and Teaching and approved by the Animal Care and Use Committee of Qingdao Agricultural University.

\section{In vitro experiment}

The White Leghorn chickens of five (60 d) were euthanized with sodium pentobarbitone and hepatocytes were obtained by collagenase perfusion and cultured in serum-free culture. The hepatocyte monolayer was treated respectively with serum-free medium, COS $(10 \mathrm{mg} / \mathrm{L})$, $\mathrm{Na}_{2} \mathrm{SeO}_{3}(1.5 \mu \mathrm{mol} / \mathrm{L}$, analytical grade, $>98.5 \%), \mathrm{COS}-\mathrm{Se}(1.5 \mu \mathrm{mol} / \mathrm{L} \mathrm{Se}$

$+10 \mathrm{mg} / \mathrm{L} \mathrm{COS})$, LS-COS (3mg/L Sulfate $+10 \mathrm{mg} / \mathrm{L} \mathrm{COS})$ and 
LS-COS-Se $(1.5 \mu \mathrm{mol} / \mathrm{L} \mathrm{Se}+3 \mathrm{mg} / \mathrm{L}$ Sulfate $+10 \mathrm{mg} / \mathrm{L} \mathrm{COS})$ on a 6-well plate. After 24 hours of incubation, the culture medium and hepatocytes were collected and preserved respectively.

\section{In vivo experiment}

A total of 240 7-days-old White Leghorn chickens without specific pathogen (body weight of $45.0 \pm 2.0 \mathrm{~g}$ ) were purchased from the Institute of Animal Husbandry and Veterinary Medicine of Shandong Academy of Agricultural Sciences and were randomly assigned to 6 groups with 4 replicates and 10 chickens per replicate, including 6 treatments: the control group was supplied with a basal diet, the COS group was supplied with an additional $30 \mathrm{mg} / \mathrm{kg} \mathrm{COS}$, the $\mathrm{Na}_{2} \mathrm{SeO}_{3}$ group was supplied with an additional $0.3 \mathrm{mg} / \mathrm{kg} \mathrm{Na}_{2} \mathrm{SeO}_{3}$ (analytical grade, $>98.5 \%$ ), the COS-Se group was supplied with an additional $0.3 \mathrm{mg} / \mathrm{kg}$ COS-Se, the LS-COS group was supplied with an additional $6.0 \mathrm{mg} / \mathrm{kg} \mathrm{LS}-\mathrm{COS}$, and the LS-COS-Se group was supplied with an additional $36.3 \mathrm{mg} / \mathrm{kg}$ LS-COS-Se.

The basal diet was formulated in accordance with the dietary guidelines established by the National Research Council to meet nutritional requirements (Table 1).

Table 1 Formulation and proximate composition of experimental diets

\begin{tabular}{llll}
\hline \hline Ingredient (\%) & & \multicolumn{2}{c}{ Chemical composition } \\
\hline Corn & 66.15 & Gross energy $(\mathrm{kcal} / \mathrm{kg})$ & 2843 \\
Soybean meal & 27.0 & Crude protein $(\%)(\mathrm{DM})$ & 19.0 \\
Fish meal & 3.30 & Calcium $(\%)$ & 0.91 \\
\hline
\end{tabular}




\begin{tabular}{llll}
\hline Dicalcium phosphate & 1.20 & Available phosphorus(\%) & 0.41 \\
Limestone & 1.00 & Lysine(\%) & 1.03 \\
Salt $(\mathrm{NaCl})$ & 0.25 & Methionine(\%) & 0.44 \\
DL-Methionine & 0.10 & Methionine+cystine(\%) & 0.78 \\
Mineral premix $^{\mathrm{a}}$ & 0.50 & & \\
Vitamin premix $^{\mathrm{b}}$ & 0.50 & & \\
Total & 100 & & \\
\hline
\end{tabular}

${ }^{a}$ Mineral premix supplied the following per kilogram of complete feed: $\mathrm{ZnSO}_{4}, 80 \mathrm{mg} ; \mathrm{MnSO}_{4}, 100 \mathrm{mg} ; \mathrm{FeSO}_{4}, 80 \mathrm{mg}$; $\mathrm{CuSO}_{4}, 6 \mathrm{mg}$; KI, 0.35 $\mathrm{mg} ; \mathrm{CoCl}_{2}, 0.4 \mathrm{mg}$.

b Vitamin premix supplied the followings per $\mathrm{kg}$ of complete feed: vitamin $A: 4000 \mathrm{IU}$; vitamin $\mathrm{B}_{1}: 1.8 \mathrm{mg}$; vitamin $\mathrm{B}_{2}: 3.6 \mathrm{mg}$; vitamin $\mathrm{B}_{12}$ : $0.01 \mathrm{mg}$; vitamin $\mathrm{D}_{3}: 800 \mathrm{IU}$; vitamin $\mathrm{E}: 10 \mathrm{IU}$; vitamin $\mathrm{K}: 0.5 \mathrm{mg}$; biotin: $0.15 \mathrm{mg}$; choline: $1300 \mathrm{mg}$; folacin: $0.55 \mathrm{mg} / \mathrm{kg}$; niacin: $30 \mathrm{mg}$; pantothenic acid: $10 \mathrm{mg}$.

Chickens were raised in airtight and ventilated buildings, provided with continuous light, water and feed at will. All experimental chickens were healthy during the feeding period (28d). On d 0,14 and 28, the chickens were weighed, and feed consumption was recorded by replication. Average daily feed intake (ADG), average daily gain (ADFI), and feed/gain ratio $(\mathrm{F} / \mathrm{G})$ were calculated. At 14 and $28 \mathrm{~d}$ of the feeding experiment, 12 chickens from each group were randomly selected and euthanized with sodium pentobarbitone, and blood samples were collected via $10 \mathrm{~mL}$ vacutainer tubes that contained EDTA as an anticoagulant. And the plasma samples were then centrifuged at $3500 \times \mathrm{g}$ for $10 \mathrm{~min}$ at $4{ }^{\circ} \mathrm{C}$. The livers were collected and immediately frozen in liquid nitrogen.

\section{Analysis of antioxidant properties}


The activity of lactate dehydrogenase (LDH), TrxR, anti-superoxide anion radical $\left(\mathrm{AntiO}_{2}^{-}\right)$, superoxide dismutase (SOD), catalase (CAT), peroxidase (POD) and the contents of malondialdehyde (MDA) in the culture medium and plasma were determined according to LDH activity assay kit (Colorimetric method), TrxR activity assay kit (Colorimetric method), $\mathrm{AntiO}_{2}{ }^{-}$activity assay kit (enzyme-linked immunosorbent assay method), SOD activity assay kit (WST-1 cell proliferation reagent method), CAT activity assay kit (Colorimetric method), POD activity assay kit (Colorimetric method) and MDA assay kit (thiobarbituric acid method) (Nanjing Jiancheng Bioengineering company, Jiangsu, China), respectively.

Real-time quantitative polymerase chain reaction (qRT-PCR) for the relative measurement of transcripts and quantification of TrxR

The mRNA levels of thioredoxin reductase 1 (TrxR-1) and thioredoxin reductase 3 (TrxR-3) in hepatocytes and liver were detected by SYBR green RT-PCR. Total RNA was extracted from hepatocytes and liver tissue using TRIzol Reagent (Sangon Biotech Co., Ltd., Shanghai, China) and cDNA was synthesized using the instruction of AMV First Strand cDNA Synthesis Kit (Sangon Biotech Co., Ltd., Shanghai, China). Software Premier 5.0 (produced by Premier Biosoft International, USA) was used to design specific primers for TrxR-1, TrxR-3 and $\beta$-actin (Table 2). RT-PCR composition ( $10 \mu \mathrm{L}$ of $2 \times$ SybrGreen $\mathrm{qPCR}$ Master Mix, 1.0 
$\mu \mathrm{L}$ of each primer, $1.0 \mu \mathrm{L}$ of cDNA template and $7.0 \mu \mathrm{L}$ of $\mathrm{ddH}_{2} \mathrm{O}$ ) were mixed together and performed on an ABI Real-time PCR System (Stepone plus, Applied Biosystems, USA). The PCR procedure consisted of at $95^{\circ} \mathrm{C}$ for $2 \mathrm{~min}$ followed by 38 cycles consisting of $95{ }^{\circ} \mathrm{C}$ for $10 \mathrm{~s}$ and $60^{\circ} \mathrm{C}$ for $30 \mathrm{~s}$. Only one peak for each PCR product was shown with the melting curve analysis. Relative quantification analysis of mRNA levels was performed using the $2^{-\Delta \Delta \mathrm{Ct}}$ method [18]. All data for each target transcript were normalized to the mRNA level of the $\beta$-actin gene.

Table 2 Primer sequences used for quantitative real-time PCR assay.

\begin{tabular}{|c|c|c|c|}
\hline $\begin{array}{l}\text { Gene } \\
\text { name }^{\mathrm{a}}\end{array}$ & $\begin{array}{l}\text { Forward primer (5' } \\
\left.\text { to } 3^{\prime}\right)\end{array}$ & $\begin{array}{l}\text { Reverse primer }\left(5^{\prime}\right. \\
\left.\text { to } 3^{\prime}\right)\end{array}$ & $\begin{array}{l}\text { Lengt } \\
\mathrm{h}\end{array}$ \\
\hline$\beta$-actin & tttgtatcttccgcc & $\begin{array}{l}\text { ccacatactggcactttactc } \\
\text { cta }\end{array}$ & $\begin{array}{l}147 \\
b p\end{array}$ \\
\hline TrxR-1 & $\begin{array}{l}\text { tcaagaatgtcaccgcaagt } \\
\mathrm{t}\end{array}$ & $\begin{array}{l}\text { cacgcagataacatcccca } \\
\text { at }\end{array}$ & $\begin{array}{l}129 b \\
p\end{array}$ \\
\hline TrxR-3 & tgttttgatagccattggtcg & $\begin{array}{l}\text { cataaggcacattggttcgtt } \\
\text { c }\end{array}$ & $\begin{array}{l}128 \\
b p\end{array}$ \\
\hline
\end{tabular}

\section{Statistical Analysis}

All the data from experiment were expressed the means \pm standard deviation and analyzed by using the one-way using the IBM SPSS 22.0 statistical software (SPSS Institute Inc., Chicago, USA). The least significant difference of multiple comparisons was used to determine differences between means. Differences were considered as significant at $P<0.05$ for all tests.

\section{RESULTS}




\section{Effect of LS-COS-Se on metabolic index of hepatocytes in vitro}

As shown in Fig. 1, compared with the control and COS groups, the activity of LDH significantly decreased in LS-COS-Se group $(P<0.05)$. There was no significant difference $(P>0.05)$ in $\mathrm{Na}_{2} \mathrm{SeO}_{3}, \mathrm{COS}-\mathrm{Se}$, LS-COS and LS-COS-Se groups.

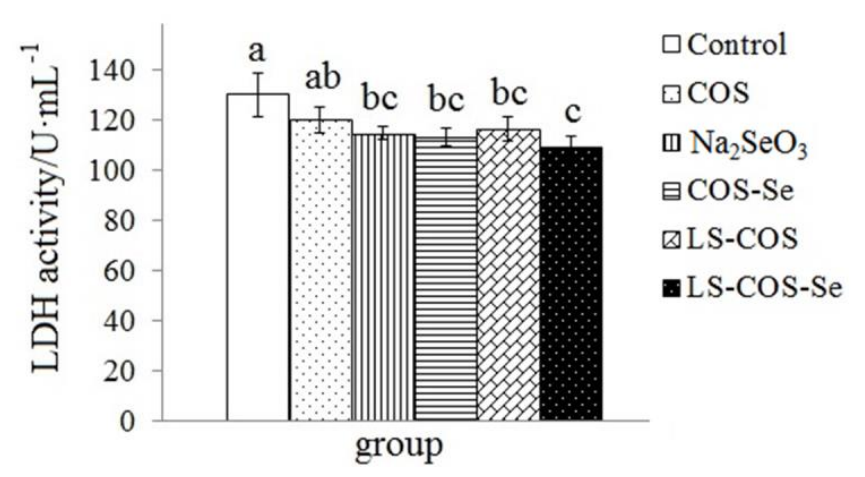

Fig. 1 The LDH activity was shown with serum-free medium, COS, $\mathrm{Na}_{2} \mathrm{SeO}_{3}, \mathrm{COS}-\mathrm{Se}$, LS-COS and LS-COS-Se in the culture medium of hepatocytes in vitro. Control group treated with serum-free medium without Se, sulfate and $\mathrm{COS}$, $\mathrm{COS}$ group treated with $\mathrm{COS}, \mathrm{Na}_{2} \mathrm{SeO}_{3}$ group treated with $\mathrm{Na}_{2} \mathrm{SeO}_{3}$, COS-Se group treated with COS-Se, LS-COS group treated with LS-COS, LS-COS-Se group treated with LS-COS-Se. Data are presented as means \pm SD $(n=3)$. a-c: means in same row with different superscripts significantly differ $(P<0.05)$.

Effect of LS-COS-Se on antioxidant capacity of hepatocytes in vitro

As shown in Fig. 2, compared with the control, COS and LS-COS groups, the activities of TrxR, SOD and CAT significantly increased in 
selenium group $(P<0.05)$, but MDA content significantly decreased $(P<$ 0.05) in $\mathrm{Na}_{2} \mathrm{SeO}_{3}, \mathrm{COS}-\mathrm{Se}$ and LS-COS-Se groups. As compared with the control group, the activity of CAT enzyme in COS group, TrxR and CAT enzyme in LS-COS group significantly increased $(P<0.05)$. As compared with control and COS groups, the activity of SOD enzyme in LS-COS group significantly increased $(P<0.05)$, but the MDA content significantly decreased $(P<0.05)$. As compared with $\mathrm{Na}_{2} \mathrm{SeO}_{3}$ and COS-Se groups, the activity of SOD enzyme in LS-COS-Se group significantly increased $(P<0.05)$. As compared with $\mathrm{Na}_{2} \mathrm{SeO}_{3}$ and LS-COS-Se groups, the activity of CAT enzyme in COS-Se group significantly increased $(P<0.05)$. As compared with the control group, the activities of $\mathrm{AntiO}_{2}^{-}$and POD enzyme in $\mathrm{COS}, \mathrm{Na}_{2} \mathrm{SeO}, \mathrm{COS}-\mathrm{Se}$, LS-COS, and LS-COS-Se groups significantly increased $(P<0.05)$. As compared with LS-COS group, the $\mathrm{AntiO}_{2}^{-}$enzyme activity in COS, $\mathrm{Na}_{2} \mathrm{SeO}_{3}$ and LS-COS-Se groups significantly increased $(P<0.05)$. As compared with COS, LS-COS and LS-COS-Se groups, the POD enzyme activity of $\mathrm{Na}_{2} \mathrm{SeO}_{3}$ and COS-Se groups significantly increased $(P<$ $0.05)$. 


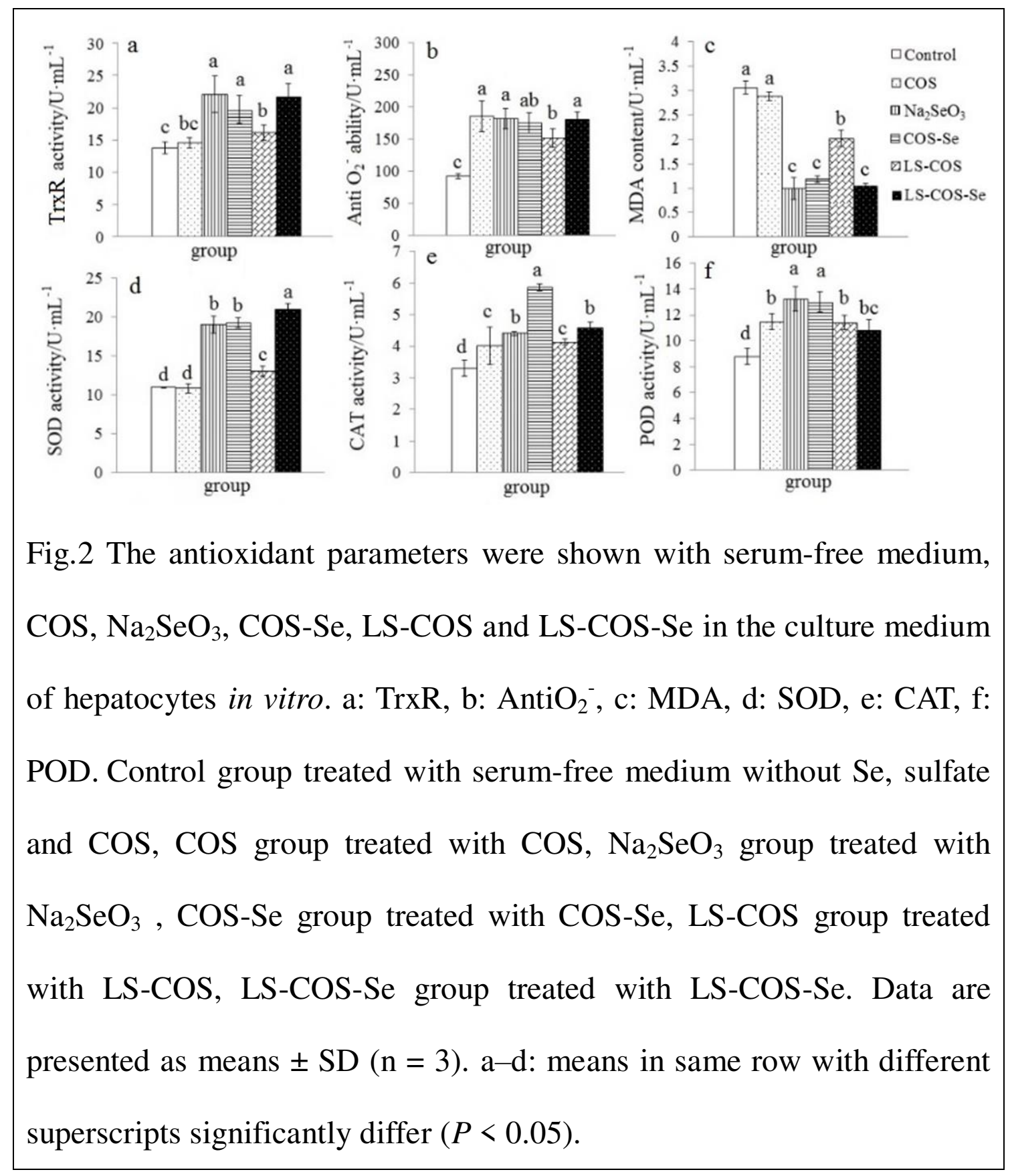

As shown in Fig.3, compared with control, $\mathrm{COS}, \mathrm{Na}_{2} \mathrm{SeO}_{3}$ and LS-COS groups, the level of TrxR-1mRNA significantly increased in COS-Se and LS-COS-Se groups $(P<0.05)$. As compared with COS-Se group, the level of TrxR-1 mRNA significantly increased in LS-COS-Se group $(P<0.05)$. As compared with control, $\mathrm{COS}, \mathrm{Na}_{2} \mathrm{SeO}_{3}$, LS-COS and 
COS-Se groups, the level of TrxR-3 mRNA significantly increased in LS-COS-Se group $(P<0.05)$. As compared with control and COS groups, the level of TrxR-3 mRNA significantly increased in $\mathrm{Na}_{2} \mathrm{SeO}_{3}$ and LS-COS groups $(P<0.05)$.

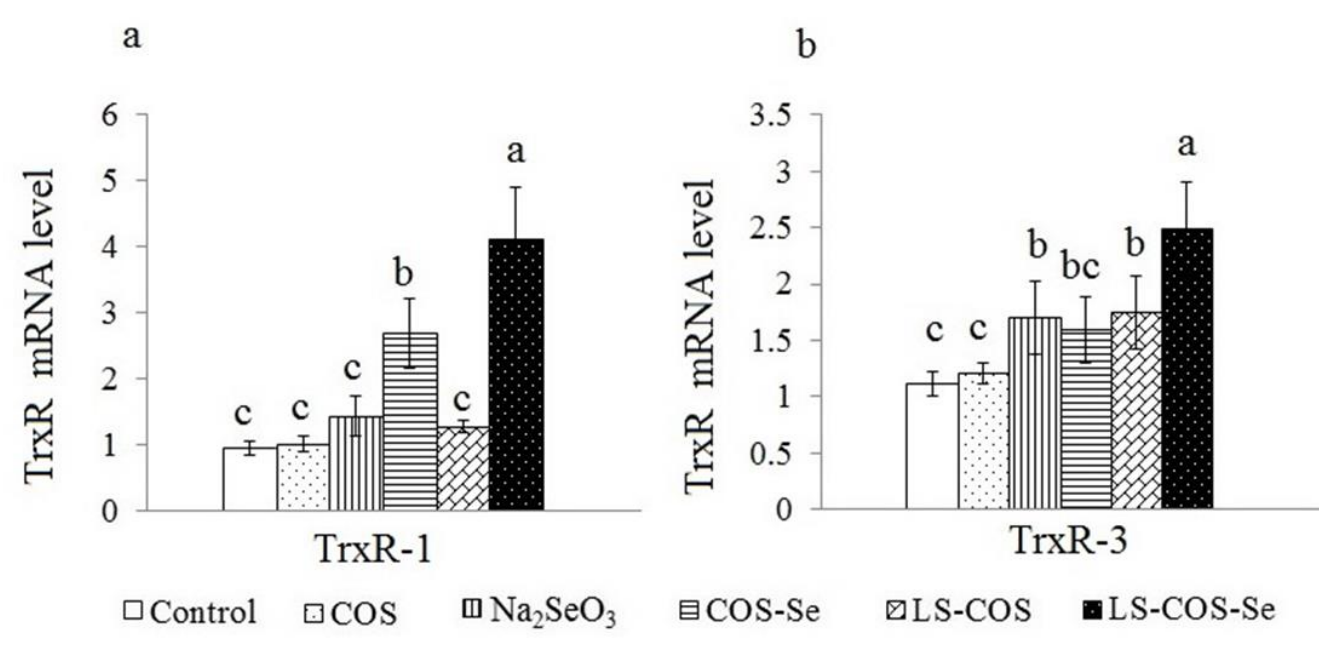

Fig. 3 The level of TrxR-1 and TrxR-3 mRNA hepatocyte culture medium were shown in basal diet, $\mathrm{COS}, \mathrm{Na}_{2} \mathrm{SeO}_{3}, \mathrm{COS}-\mathrm{Se}, \mathrm{LS}-\mathrm{COS}$ and LS-COS-Se in vitro. a: TrxR-1, b: TrxR-3. Control group treated with serum-free medium without Se, sulfate and COS, COS group treated with COS, $\mathrm{Na}_{2} \mathrm{SeO}_{3}$ group treated with $\mathrm{Na}_{2} \mathrm{SeO}_{3}$, COS-Se group treated with COS-Se, LS-COS group treated with LS-COS, LS-COS-Se group treated with LS-COS-Se. Data are presented as means \pm SD $(n=3)$. a-c: means in same row with different superscripts significantly differ $(P<0.05)$.

Effect of LS-COS-Se on the growth performance of chickens in vivo

Compared with the control diet, supplementation with $\mathrm{COS}, \mathrm{Na}_{2} \mathrm{SeO}_{3}$, 
COS-Se, LS-COS and LS-COS-Se did not significantly improve the $\mathrm{ADFI}, \mathrm{ADG}$ and $\mathrm{F} / \mathrm{G}$ of chickens during the experimental period of 4 weeks (Fig. 4a, 4b, 4c). However, compared with the control diet, supplementation with $\mathrm{COS}, \mathrm{Na}_{2} \mathrm{SeO}_{3}, \mathrm{COS}-\mathrm{Se}$, LS-COS and LS-COS-Se significantly increased the baby weight on $14 \mathrm{~d}$ and $28 \mathrm{~d}(P<0.05)$. On 28d, compared with $\mathrm{COS}, \mathrm{Na}_{2} \mathrm{SeO}_{3}$ and LS-COS groups, the baby weight of COS-Se and LS-COS-Se groups was significantly increased $(P<0.05)$. As compared with COS-Se group, the baby weight of dietary supplementation with LS-COS-Se was significantly increased $(P<0.05)$ (Fig. 4d).

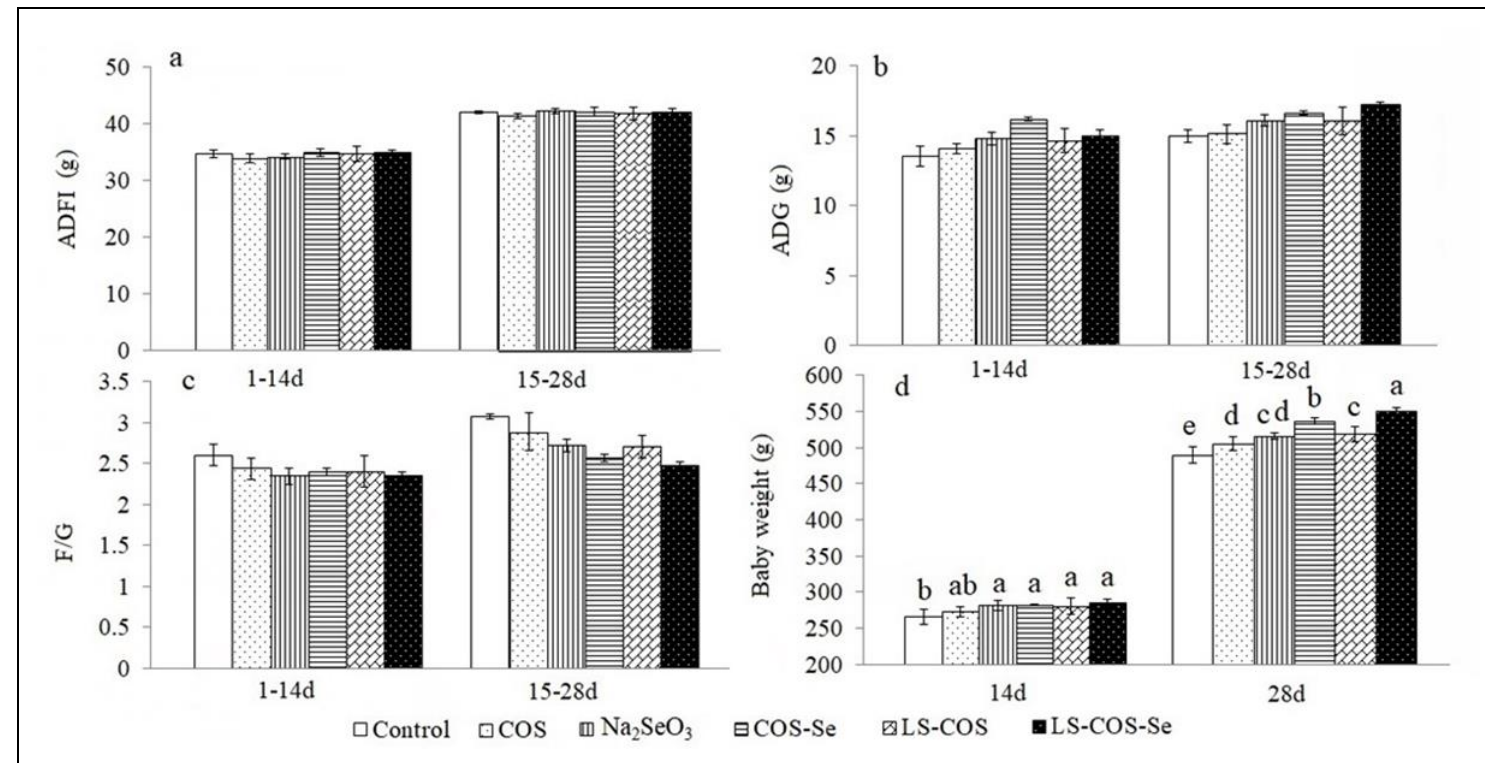

Fig. 4 The growth performance (ADFI a, ADG b, F/G c and Baby weight d) of laying hens were shown with basal diet, $\mathrm{COS}, \mathrm{Na}_{2} \mathrm{SeO}_{3}, \mathrm{COS}-\mathrm{Se}$, LS-COS and LS-COS-Se in vivo on $14 \mathrm{~d}$ and 28d. ADFI: average daily feed intake; ADG: average daily weight gain; F/G: ratio of feed to gain; Control group treated with basal diet, COS group treated with COS, 
$\mathrm{Na}_{2} \mathrm{SeO}_{3}$ group treated with $\mathrm{Na}_{2} \mathrm{SeO}_{3}$, COS-Se group treated with COS-Se, LS-COS group treated with LS-COS, LS-COS-Se group treated with LS-COS-Se. Data are presented as means \pm SD $(n=5)$. a-e: means in same row with different superscripts significantly differ $(P<0.05)$.

\section{Effect of LS-COS-Se on the antioxidant capacity of chickens in vivo}

As shown in Fig. 5, compared with control and COS groups, plasma TrxR enzyme activity significantly increased after adding $\mathrm{Na}_{2} \mathrm{SeO}_{3}$, COS-Se, LS-COS and LS-COS-Se $(14 \mathrm{~d})(P<0.05)$. As compared with $\mathrm{Na}_{2} \mathrm{SeO}_{3}$, COS-Se and LS-COS groups, plasma TrxR activity significantly increased after adding LS-COS-Se $(14 d)(P<0.05)$. As compared with control group, COS and LS-COS groups, plasma TrxR activity significantly increased after adding $\mathrm{Na}_{2} \mathrm{SeO}_{3}$ and LS-COS-Se (28d) $(P<0.05)$. As compared with control, COS and LS-COS groups, plasma $\mathrm{AntiO}_{2}^{-}$enzyme activity significantly increased in selenium supplemented groups $\left(\mathrm{Na}_{2} \mathrm{SeO}_{3}, \mathrm{COS}-\mathrm{Se}\right.$, and LS-COS-Se) (14d and 28d) $(P<0.05)$. As compared with the control and COS groups, the plasma $\mathrm{AntiO}_{2}{ }^{-}$enzyme activity significantly increased in the LS-COS group (14d and 28d) $(P<0.05)$. As compared with $\mathrm{Na}_{2} \mathrm{SeO}_{3}$ and COS-Se groups, plasma $\mathrm{AntiO}_{2}{ }^{-}$enzyme activity significantly increased (14d) $(P<$ 0.05). Compared with COS-Se and LS-COS groups, the plasma MDA content in $\mathrm{Na}_{2} \mathrm{SeO}_{3}$ group significantly decreased $(14 \mathrm{~d})(P<0.05)$. As 
compared with control, $\mathrm{COS}, \mathrm{Na}_{2} \mathrm{SeO}_{3}, \mathrm{COS}-\mathrm{Se}$ and LS-COS groups, plasma MDA content significantly decreased after adding LS-COS-Se (28d) $(P<0.05)$. As compared with control, COS and LS-COS group, plasma MDA content significantly decreased after adding $\mathrm{Na}_{2} \mathrm{SeO}_{3}$ (28d) $(P<0.05)$. As compared with the control group, the content of plasma MDA in the group supplemented with COS-Se, significantly decreased (28d) $(P<0.05)$. As compared with the control group, the plasma SOD activity significantly increased after adding $\mathrm{COS}, \mathrm{Na}_{2} \mathrm{SeO}_{3}$, LS-COS,COS-Se and LS-COS-Se $(14 \mathrm{~d}$ and $28 \mathrm{~d})(P<0.05)$. As compared with $\mathrm{COS}, \mathrm{Na}_{2} \mathrm{SeO}_{3}$ and LS-COS groups, the enzyme activity of plasma SOD significantly increased after adding COS-Se and LS-COS-Se (14d) $(P<0.05)$. As compared with the COS group, the plasma SOD enzyme activity significantly increased after adding $\mathrm{Na}_{2} \mathrm{SeO}_{3}(14 \mathrm{~d})(P<0.05)$. As compared with control, $\mathrm{COS}, \mathrm{Na}_{2} \mathrm{SeO}_{3}$, LS-COS and COS-Se groups, plasma SOD enzyme activity significantly increased after adding LS-COS-Se $(28 \mathrm{~d})(P<0.05)$. Compared with control and COS groups, the plasma SOD enzyme activity significantly increased after adding LS-COS and LS-COS-Se (28d) $(P<0.05)$. As compared with control, COS, $\mathrm{Na}_{2} \mathrm{SeO}_{3}$ and LS-COS groupS, plasma CAT activity significantly increased after adding COS-Se $(14 \mathrm{~d})(P<0.05)$. As compared with the control group, the activity of plasma CAT enzyme significantly decreased after adding $\mathrm{Na}_{2} \mathrm{SeO}_{3}$ and COS-Se $(28 \mathrm{~d})(P<0.05)$. As compared with 
COS group, the activity of plasma CAT significantly decreased after adding $\mathrm{Na}_{2} \mathrm{SeO}_{3}$, COS-Se and LS-COS-Se (28d) $(P<0.05)$. As compared with COS group, plasma POD activity significantly increased after adding $\mathrm{Na}_{2} \mathrm{SeO}_{3}$, LS-COS and LS-COS-Se (14d) $(P<0.05)$.

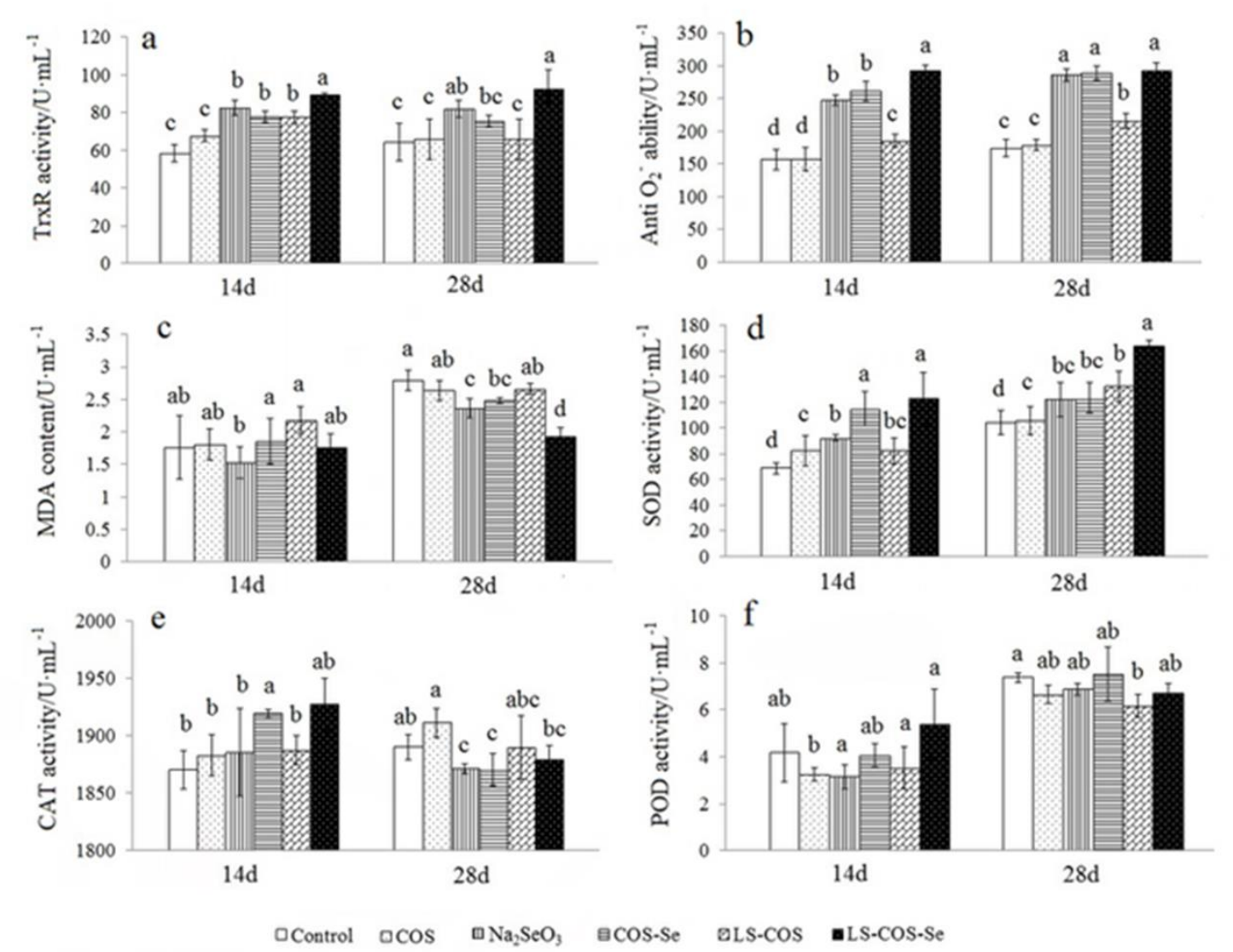

Fig. 5. The antioxidant parameters of plasma were shown with basal diet, COS, $\mathrm{Na}_{2} \mathrm{SeO}_{3}, \mathrm{COS}-\mathrm{Se}$, LS-COS and LS-COS-Se in vivo on $14 \mathrm{~d}$ and 28d. a: TrxR, b: $\operatorname{AntiO}_{2}^{-}$, c: MDA, d: SOD, e: CAT, f: POD. Control group treated with basal diet, $\mathrm{COS}$ group treated with $\mathrm{COS}, \mathrm{Na}_{2} \mathrm{SeO}_{3}$ group treated with $\mathrm{Na}_{2} \mathrm{SeO}_{3}$, COS-Se group treated with COS-Se, LS-COS group treated with LS-COS, LS-COS-Se group treated with 
LS-COS-Se. Data are presented as means \pm SD $(n=5)$. a-d: means in same row with different superscripts significantly differ $(P<0.05)$.

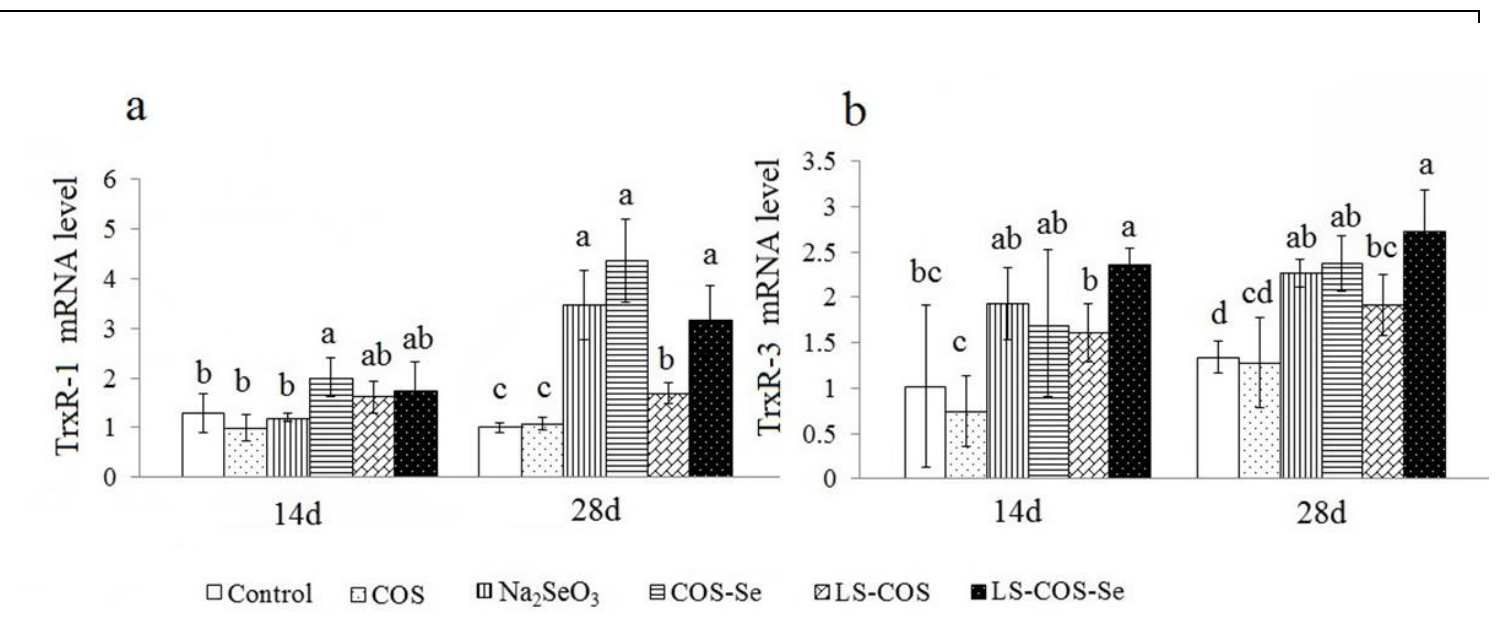

Fig. 6. The level of TrxR-1 and TrxR-3 mRNA of liver tissue were shown in basal diet, $\mathrm{COS}, \mathrm{Na}_{2} \mathrm{SeO}_{3}, \mathrm{COS}-\mathrm{Se}$, LS-COS and LS-COS-Se in vivo on $14 \mathrm{~d}$ and $28 \mathrm{~d}$. a: TrxR-1, b: TrxR-3. Control group treated with basal diet, $\mathrm{COS}$ group treated with $\mathrm{COS}, \mathrm{Na}_{2} \mathrm{SeO}_{3}$ group treated with $\mathrm{Na}_{2} \mathrm{SeO}_{3}$, COS-Se group treated with COS-Se, LS-COS group treated with LS-COS, LS-COS-Se group treated with LS-COS-Se. Data are presented as means $\pm \mathrm{SD}(\mathrm{n}=5)$. a-c: means in same row with different superscripts significantly differ $(P<0.05)$.

As shown in Fig. 6, compared with control, $\mathrm{COS}$ and $\mathrm{Na}_{2} \mathrm{SeO}_{3}$ groups, basal diet supplemented with COS-Se could significantly increase the level of TrxR-1 mRNA in liver $(14 \mathrm{~d})(P<0.05)$. As compared with 
control, COS and LS-COS groups, basal diet supplemented with selenium supplementation $\left(\mathrm{Na}_{2} \mathrm{SeO}_{3}, \mathrm{COS}-\mathrm{Se}\right.$ and LS-COS-Se) could significantly increase the level of TrxR-1mRNA in liver $(28 \mathrm{~d})(P<0.05)$. As compared with control and COS groups, basal diet supplemented with LS-COS could significantly increase the level of TrxR-1mRNA in liver (28d) $(P<$ 0.05). As compared with control, COS and LS-COS groups, basal diet supplemented with selenium supplementation $\left(\mathrm{Na}_{2} \mathrm{SeO}_{3}, \mathrm{COS}-\mathrm{Se}\right.$ and LS-COS-Se) significantly increased the level of TrxR-3 mRNA in liver (14d) $(P<0.05)$. As compared with COS group, basal diet supplemented with LS-COS could significantly increase the level of TrxR-3 mRNA in liver $(14 \mathrm{~d})(P<0.05 \mathrm{~d})$. As compared with control group and COS group, basal diet supplemented with selenium supplementation $\left(\mathrm{Na}_{2} \mathrm{SeO}_{3}\right.$, COS-Se and LS-COS-Se) significantly increased the level of TrxR-3 mRNA in liver $(28 \mathrm{~d})(P<0.05)$. As compared with the control group, basal diet supplemented with LS-COS significantly increased the level of TrxR-1 mRNA in the liver $(14 \mathrm{~d})(P<0.05)$.

\section{DISCUSSION}

LDH is a cytoplasmic enzyme and is released after cell death [19]. In this study, LS-COS-Se could improve the proliferation of hepatocytes by significantly decreasing the LDH content. At the cellular level, superoxide anions, hydrogen peroxide and hydroxyl radicals which exceeding the antioxidant protection levels can cause widespread damage 
to DNA, proteins and endogenous lipids [20]. To investigate the effect of LS-COS-Se on the anti-oxidation ability of hepatocytes and chickens in vitro and in vivo, we determined the concentrations of six enzymes (TrxR, $\left.\mathrm{AntiO}_{2}^{-}, \mathrm{MDA}, \mathrm{SOD}, \mathrm{CAT}, \mathrm{POD}\right)$ and the relative mRNA levels of genes (TrxR-1, TrxR-3). We observed that LS-COS-Se showed the better biological activity. But there were no significant difference in the ADFI, $\mathrm{ADG}$ and $\mathrm{F} / \mathrm{G}$ of chickens during the experimental period of 4 weeks in vivo.

COS is a positively charged alkaline antioxidant, which scavenges free radicals and promotes metabolism by absorbing all kinds of negatively charged toxic substances $[21,22]$. As a kind of macromolecular active substance formed by sulfation modification of polysaccharides, polysaccharide sulfate reflects its antioxidant ability by enhancing the scavenging ability of alkyl free radicals, hydroxyl radicals and superoxide anions [23-25]. This study confirmed the antioxidant effects of COS and sulfate (LS-COS) in vivo and in vitro, and the antioxidant activity of LS-COS treatment group was better than that of COS treatment group. The results further showed that sulfation modification could enhance the antioxidant capacity of LS-COS in vivo and in vitro [26].

Selenium plays an antioxidant role by reducing the content of peroxides and preventing the formation of harmful free radicals through 
the regulation and catalysis of antioxidant enzymes [27, 28]. Surai et al. analyzed the current results on selenium in antioxidant defenses in poultry clearly showed its modulatory effect on developing embryos, newly hatched chicks, and postnatal chickens [29]. Peng et al. reported that there was no distinction in elevating activities of GPx and TrxR between selenosulfate and selenite in vitro [30]. In this experiment, compared with the control group and COS group, different selenium treatments $\left(\mathrm{Na}_{2} \mathrm{SeO}_{3}, \mathrm{COS}-\mathrm{Se}\right.$ and LS-COS-Se) showed higher TrxR-1 and SOD enzyme activities, TrxR-1 and TrxR-3 mRNA levels and lower MDA content in vivo and in vitro. These results further prove that selenium supplementation can improve the antioxidant function in vivo and in vitro through TrxR. After selenium modification, the antioxidant activity of COS was significantly improved, and the antioxidant activity of COS-Se was similar to that of $\mathrm{Na}_{2} \mathrm{SeO}_{3}$, except that COS-Se had higher CAT enzyme activity and hepatocyte TrxR-1mRNA level in hepatocyte culture medium, higher plasma CAT enzyme activity, SOD enzyme activity and liver TrxR-1mRNA level (14d). Surai et al. reported that Se efficiency depends on the level of supplementation and form of dietary Se, organic Se sources being more effective modulators of the antioxidant systems in poultry than sodium selenite [29].

In this study, different selenium treatments $\left(\mathrm{Na}_{2} \mathrm{SeO}_{3}, \mathrm{COS}-\mathrm{Se}\right.$ and LS-COS-Se) showed better antioxidant activity than LS-COS treatment, 
especially increased TrxR activity, SOD activity, CAT activity and decreased MDA content in vitro, and increased $\mathrm{AntiO}_{2}{ }^{-}$enzyme activity (14d and 28d) and TrxR-1mRNA level (28d) in vivo. The results showed that the biological ability of selenium, especially its antioxidant activity, was higher than that of sulfate. We speculate that selenium compounds and sulfate may have different antioxidant activities through different antioxidant machines, but both selenium compounds and sulfate can improve oxidative stress damage $[9,31]$. In addition, because they are dependent on Se antioxidant enzymes, their expression and activity are mainly regulated by Se rather than sulfate [32]. Early study had shown that Se-CTS-S showed a better biological activity mainly benefited from the synergistic effects of Se and sulfate on GSH system [33]. Guo et al. reported that Se protected cells from oxidative damage primarily by increasing the activity of TrxR, inhibiting the activation of the MAPK signaling pathway [34]. This study showed that LS-COS-Se treatment in vitro increased the levels of TrxR-1 and TrxR-3 mRNA, and in vivo increased the activities of $\operatorname{TrxR}$ and SOD, which were significantly different from those of COS-Se and LS-COS. There were significant differences (increase) of baby weight among the LS-COS-Se group and the other supplementation groups. Then LS-COS-Se showed higher antioxidant capacity than COS-Se and LS-COS. We believe that when COS is modified by selenite and sulfation to form a compound 
(LS-COS-Se), selenium and sulfate may play an important role in synergistic enhancement of antioxidation in vivo and in vitro.

To sum up, LS-COS-Se can promote proliferation, reduce cytotoxicity and increase the expression of TrxR-1 and TrxR-3 mRNA and the activity of TrxR and SOD by activating TrxR, thus improve the antioxidant function of the body. In addition, LS-COS-Se showed good biological activity, which was mainly due to the synergistic effect of selenium and sulfate in enhancing antioxidant function.

\section{Conclusion}

The diet supplemented with LS-COS-Se improved the baby weight of laying hens without specific pathogens, improved the anti-oxidation ability of the body, and showed better biological activity, this was mainly due to the synergistic effect of $\mathrm{Se}$ and sulfate on TrxR. This work provides a fundamental basis for the future development of LS-COS-Se functional food use for improving the anti-oxidation ability of laying hens and for understanding the biological effects of LS-COS-Se and its potential as a functional feed additive.

\section{Abbreviations}

Se: Selenium; LS-COS-Se: selenated chitosan oligosaccharide sulfate; COS: chitosan oligosaccharide; $\mathrm{Na}_{2} \mathrm{SeO}_{3}$ : sodium selenite; COS-Se: selenide oligosaccharide; LS-COS: chitosan oligosaccharide; TrxR: thioredoxin reductase; $\mathrm{LDH}$ : lactate dehydrogenase; $\mathrm{AntiO}_{2}{ }^{-}$: 
anti-superoxide anion radical; SOD: superoxide dismutase; CAT: catalase; POD: peroxidase; MDA: malondialdehyde; TrxR-1: thioredoxin reductase 1; TrxR-3: thioredoxin reductase 3; SPF: specific pathogen free; ADG: average daily weight gain; ADFI: average daily feed intake; F/G: ratio of feed to gain.

\section{Acknowledgments}

The authors were grateful to their laboratory technicians for their assistance with the experimental animals and helpful and constructive advice.

\section{Authors' contributions}

The authors' contributions are as follows: L. H. designed the study and discussed the results and wrote the paper; H. Q. contributed to the cell and animal experiment; L. Z. contributed to interpretation of findings; Y. H. contributed to the data analyses; S. G. contributed to reviewing of the manuscript; F. C. was the principal investigator and in charge of the whole trial. All authors read and approved the final version of the manuscript.

\section{Funding}

This study was partly supported by Chinese National Natural Science Foundation (31001093, 31101867), Shandong modern agricultural industry technology system poultry innovation team projects (SDAIT-08-10, SDAIT-11-07), A Project of Shandong Province Higher 
Educational Science and Technology Program (J18KA131, J18KA143).

\section{Availability of data and materials}

The datasets were obtained during and/or analyzed during the current study available from the corresponding author on reasonable request.

\section{Ethics approval}

All animal protocols used in this study were in accordance with the Guidelines for the Care and Use of Animals for Research and Teaching and approved by the Animal Care and Use Committee of Qingdao Agricultural University.

\section{Consent for publication}

Not applicable.

\section{Competing interests}

The authors declare that they have no competing interests

\section{References}

1. Liu L, Wu C, Chen D, Yu B, Huang Z, Luo Y, et al. Selenium-Enriched Yeast Alleviates Oxidative Stress-Induced Intestinal Mucosa Disruption in Weaned Pigs. Oxid Med Cell Longev. 2020;5490743.

2. Hosnedlova B, Kepinska M, Skalickova S, Fernandez C, Nedecky BR , Malevu TD, et al. A Summary of New Findings on the Biological Effects of Selenium in Selected Animal Species-A 
Critical Review. Int J Mol Sci 2017;18:2209.

3. Rayman MP. The importance of selenium to human health. Lancet. 2000;356:233-41.

4. Méplan C, Hughes DJ. The Role of Selenium in Health and Disease: Emerging and Recurring Trends. Nutrients. 2020;12:1049.

5. Zhang L, Wang YX, Zhou Y, Zheng L, Zhan XA, Pu QH. Different sources of maternal selenium affect selenium retention, antioxidant status, and meat quality of 56-day-old offspring of broiler breeders. Poult Sci. 2014;93:2210-9.

6. Zhang S, Xie Y, Li M, Yang H, Li S, Li J , et al. Effects of Different Selenium Sources on Meat Quality and Shelf Life of Fattening Pigs. Animals (Basel). 2020;10:615.

7. Yin S, Wang C, Wei J, Wang D, Jin L, Liu J, et al. Essential trace elements in placental tissue and risk for fetal neural tube defects. Environ Int. 2020;139:105688.

8. Rao S, Lin Y, Du Y, He L, Huang G, Chen B, et al. Designing multifunctionalized selenium nanoparticles to reverse oxidative stress-induced spinal cord injury by attenuating ROS overproduction and mitochondria dysfunction. J Mater Chem B. 2019;7:2648-2656.

9. Yi HW, Zhu XX, Huang XL, Lai YZ, Tang Y. Selenium-enriched Bifidobacterium longum protected alcohol and high fat diet induced hepatic injury in mice. Chin J Nat Med. 2020;18:169-177. 
10. Wu M, Li J, An Y, Li P, Xiong W, Li J, et al. Chitooligosaccharides Prevents the Development of Colitis-Associated Colorectal Cancer by Modulating the Intestinal Microbiota and Mycobiota. Front Microbiol. 2019;10:2101.

11. Guan G, Azad MAK, Lin Y, Kim SW, Tian Y, Liu G, et al. Biological Effects and Applications of Chitosan and Chito-Oligosaccharides. Front Physiol. 2019;10:516.

12. Sánchez Á, Mengíbar M, Fernández M, Alemany S, Heras A, Acosta N. Influence of Preparation Methods of Chitooligosaccharides on Their Physicochemical Properties and Their Anti-Inflammatory Effects in Mice and in RAW264.7 Macrophages. Mar Drugs. 2018;16:430.

13. Dai X, Hou W, Sun Y, Gao Z, Zhu S, Jiang Z. Chitosan Oligosaccharides Inhibit/Disaggregate Fibrils and Attenuate Amyloid $\beta$-Mediated Neurotoxicity. Int J Mol Sci 2015;16:10526-10536.

14. Marmouzi I, Ezzat SM, Salama MM, Merghany RM, Attar AM, El-Desoky AM, et al. Recent Updates in Pharmacological Properties of Chitooligosaccharides. Biomed Res Int. 2019;4568039.

15. Qin S, Huang B, Ma J, Wang X, Zhang J, Li L, et al. Effects of selenium-chitosan on blood selenium concentration, antioxidation status, and cellular and humoral immunity in mice. Biol. Trace Elem. 
Res. 2015;165:145-152.

16. Li J, Cheng Y, Chen Y, Qu H, Zhao Y, Wen C, et al. Dietary Chitooligosaccharide Inclusion as an Alternative to Antibiotics Improves Intestinal Morphology, Barrier Function, Antioxidant Capacity, and Immunity of Broilers at Early Age. Animals (Basel). 201;9:493.

17 Saccoccia F, Angelucci F, Boumis G, Carotti D, Desiato G, Miele AE, et al. Thioredoxin Reductase and Its Inhibitors. Curr Protein Pept Sci. 2014;15:621-46.

18. Chen F, Zhu L, Qiu H, Qin S. Selenium-enriched Saccharomyces cerevisiae improves growth, antioxidant status and selenoprotein gene expression in Arbor Acres broilers. J Anim Physiol Anim Nutr (Berl). 2017;101:259-266.

19. Wang G, Zhang J, Dewilde AH, Pal AK, Bello D, Therrien JM, et al. Understanding and correcting for carbon nanotube interferences with a commercial LDH cytotoxicity assay. Toxicology.2012;299:99-111.

20. Li R, Jia Z, Trush MA. Defining ROS in Biology and Medicine. React Oxyg Species (Apex) 2016;1:9-21.

21. Bai K, Hong B, Huang W, He J. Selenium-Nanoparticles-Loaded Chitosan/Chitooligosaccharide Microparticles and Their Antioxidant Potential: A Chemical and In Vivo Investigation. Pharmaceutics 2020;12:43. 
22. Stealey S, Guo X, Majewski R, Dyble A, Lehman K, Wedemeyer M, et al. Calcium-oligochitosan-pectin microcarrier for colonic drug delivery. Pharm Dev Technol. 2020; 25:260-265.

23. Bai K, Hong B, He J, Hong Z, Tan R. Preparation and antioxidant properties of selenium nanoparticles-loaded chitosan microspheres. Int J Nanomedicine. 2017;12:4527-4539.

24. Liu X, Chen T, Hu Y, Li K, Yan L. Catalytic synthesis and antioxidant activity of sulfated polysaccharide from Momordica charantia L. Biopolymers 2014;101:210-215.

25. Deng $\mathrm{C}, \mathrm{Xu} \mathrm{J}, \mathrm{Fu} \mathrm{H}, \mathrm{Chen} \mathrm{J}, \mathrm{Xu} \mathrm{X}$. Characterization, antioxidant and cytotoxic activity of sulfated derivatives of a water-insoluble polysaccharides from Dictyophora indusiata. Mol Med Rep. 2015;11:2991-2998.

26. Wang T, Zhou Y, Xie W, Chen L, Zheng H, Fan L. Preparation and anticoagulant activity of $\mathrm{N}$-succinyl chitosan sulfates. Int J Biol Macromol. 2012;51:808-814.

27. Zoidis E, Seremelis I, Kontopoulos N, Danezis GP. Selenium-Dependent Antioxidant Enzymes: Actions and Properties of Selenoproteins. Antioxidants (Basel). 2018;7:66.

28. Tinggi U. Selenium: its role as antioxidant in human health. Environ Health Prev Med. 2008;13:102-108.

29. Surai PF, Kochish II. Nutritional Modulation of the Antioxidant 
Capacities in Poultry: The Case of Selenium. Review Poult Sci. 2019; 98:4231-4239.

30. Peng D, Zhang J, Liu Q. Effect of Sodium Selenosulfate on Restoring Activities of Selenium-Dependent Enzymes and Selenium Retention Compared With Sodium Selenite in Vitro and in Vivo. Comparative Study Biol Trace Elem Res. 2007;117:77-88.

31. Liu Y, Yu F, Zhang B, Zhou M, Bei Y, Zhang Y, et al. Improving the protective effects of aFGF for peripheral nerve injury repair using sulfated chitooligosaccharides. Asian J Pharm Sci. 2019;14:511-520.

32. Battin EE, Brumaghim JL. Antioxidant activity of sulfur and selenium: a review of reactive oxygen species scavenging, glutathione peroxidase, and metal-binding antioxidant mechanisms. Cell Biochem Biophys. 2009;55(1):1-23.

33. Chen F, Hou L, Zhu L, Yang C, Zhu F, Qiu H, et al. Effects of selenide chitosan sulfate on glutathione system in hepatocytes and specific pathogen-free chickens. Poult Sci.2020; doi: 10.1016/j.psj.2020.04.024.

34. Guo Y, Yan S, Gong J, Jin L, Shi B. The Protective Effect of Selenium on Bovine Mammary Epithelial Cell Injury Caused by Depression of Thioredoxin Reductase. Biol Trace Elem Res. 2018;184:75-82. 


\section{Figures}

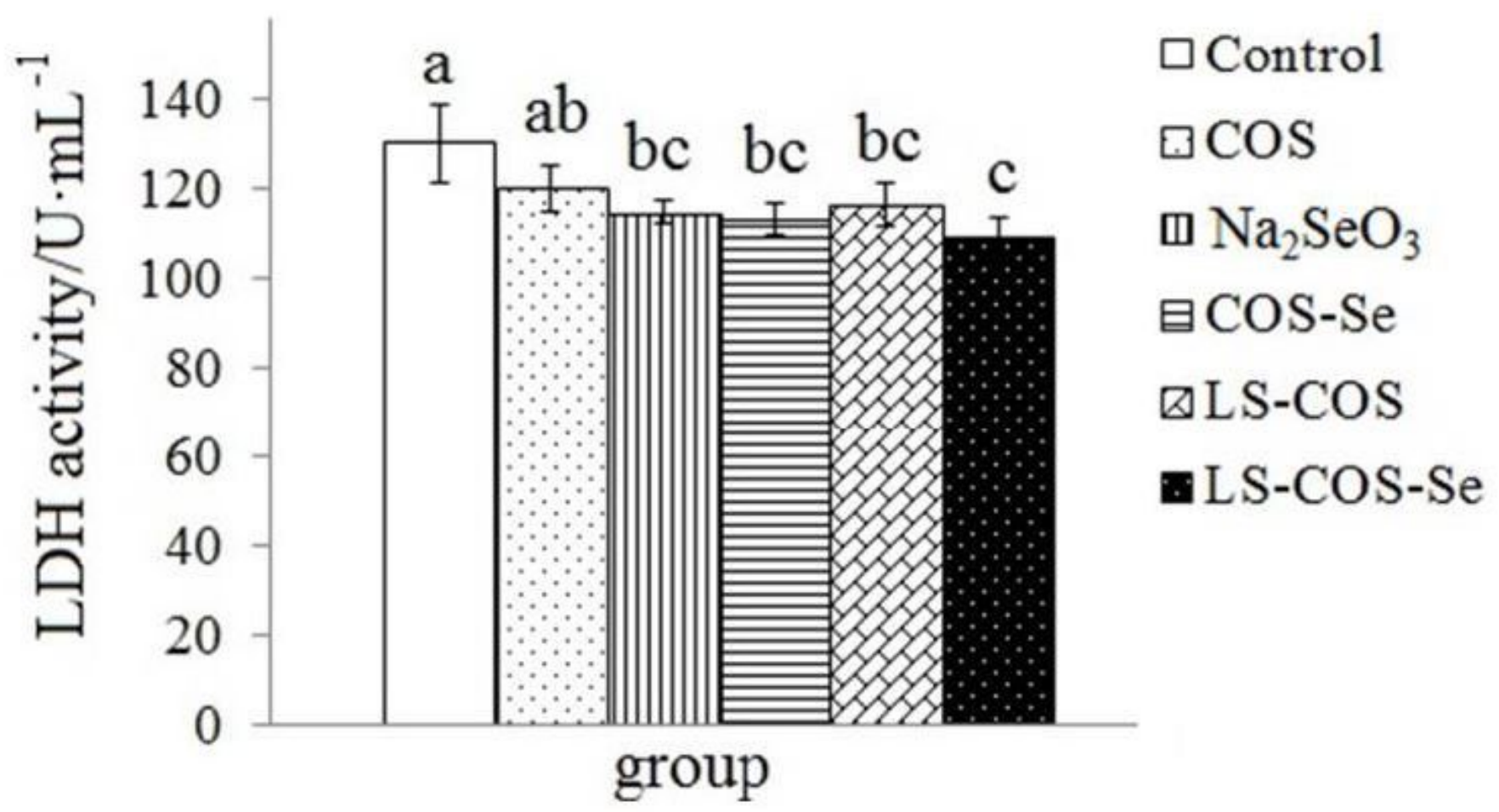

Figure 1

The LDH activity was shown with serum-free medium, COS, Na2Se03, COS-Se, LS-COS and LS-COS-Se in the culture medium of hepatocytes in vitro. Control group treated with serum-free medium without $\mathrm{Se}$, sulfate and COS, COS group treated with COS, Na2SeO3group treated with $\mathrm{Na2SeO3,} \mathrm{COS-Se} \mathrm{group}$ treated with COS-Se, LS-COS group treated with LS-COS, LS-COS-Se group treated with LS-COS-Se. Data are presented as means $\pm S D(n=3)$. a-c: meansin same row with different superscripts significantly differ $(P<0.05)$. 

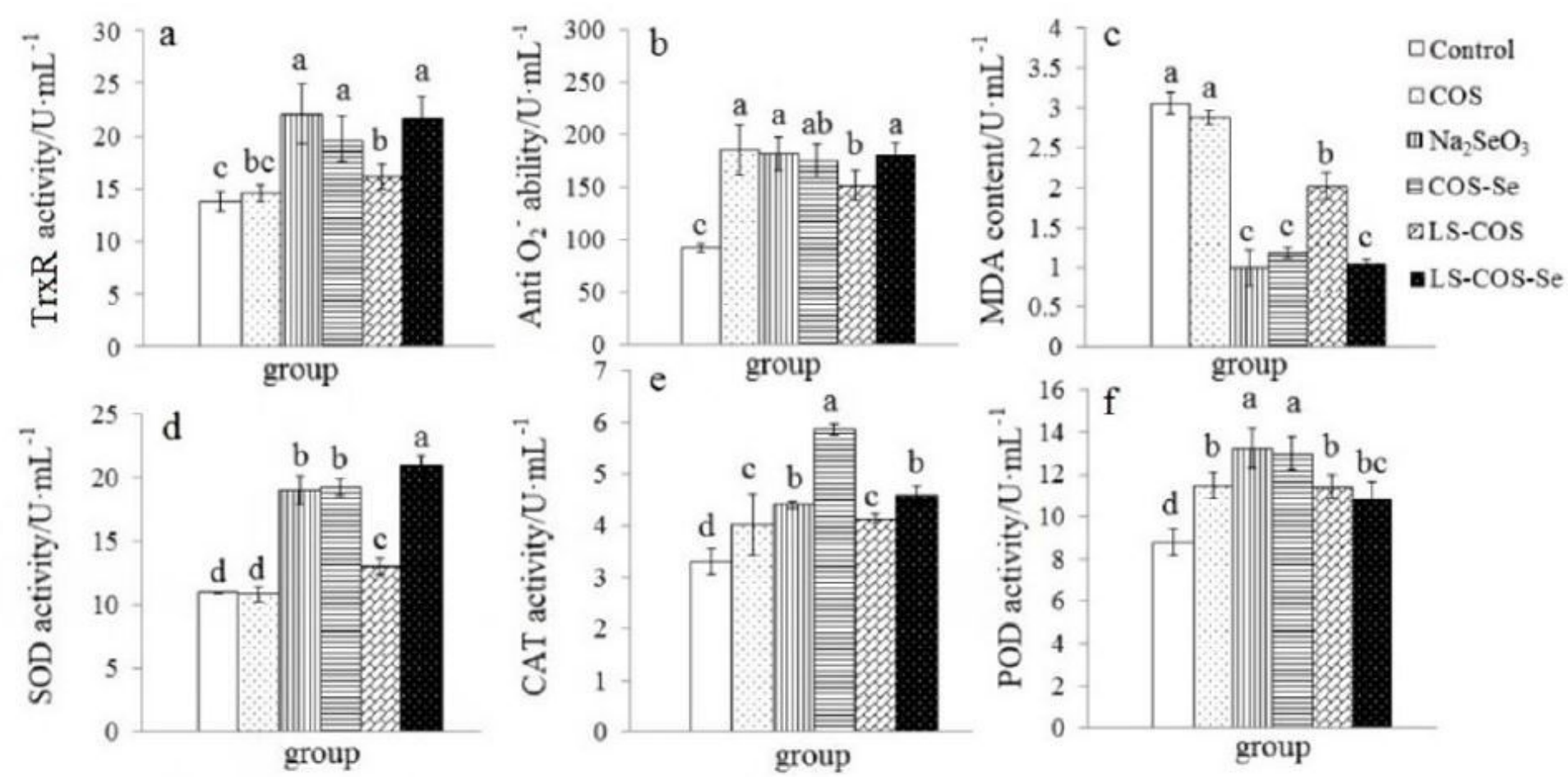

\section{Figure 2}

The antioxidant parameterswere shownwith serum-free medium, COS, Na2SeO3, COS-Se, LS-COS and LSCOS-Se in the culture medium of hepatocytes in vitro.a:TrxR, b: AntiO2-, c: MDA, d: SOD, e: CAT, f: POD.Control group treated with serum-free medium without Se, sulfate and COS, COS group treated with $\mathrm{COS}$, Na2SeO3group treated with $\mathrm{Na} 2 \mathrm{SeO} 3, \mathrm{COS}$-Se group treated with COS-Se, LS-COS group treated with LS-COS, LS-COS-Se group treated with LS-COS-Se. Data are presented as means $\pm S D(n=3)$. a-d: meansin same row with different superscripts significantly differ $(P<0.05)$.

a

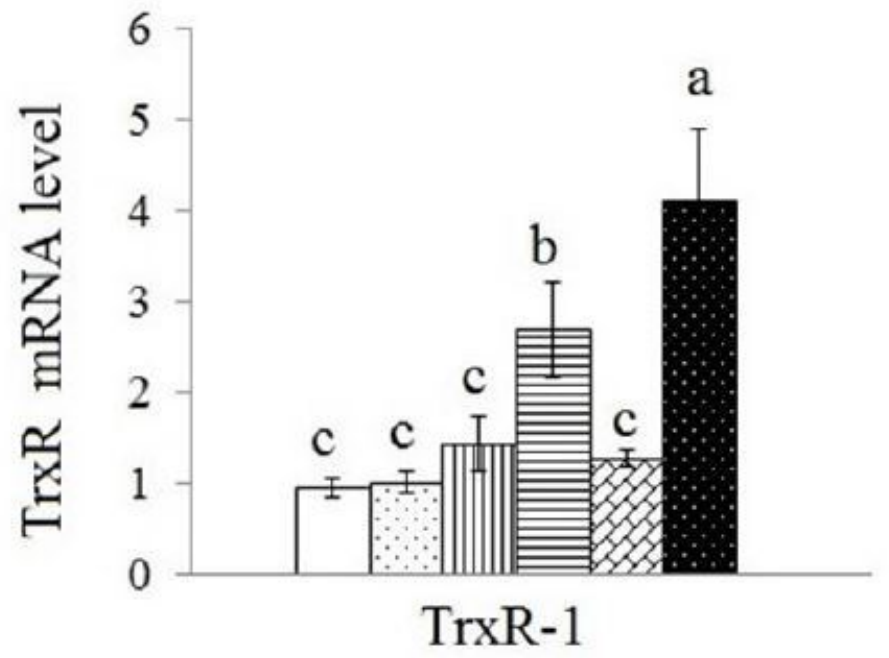

$\square$ Control $\square \mathrm{COS} \quad \square \mathrm{Na}_{2} \mathrm{SeO}_{3}$

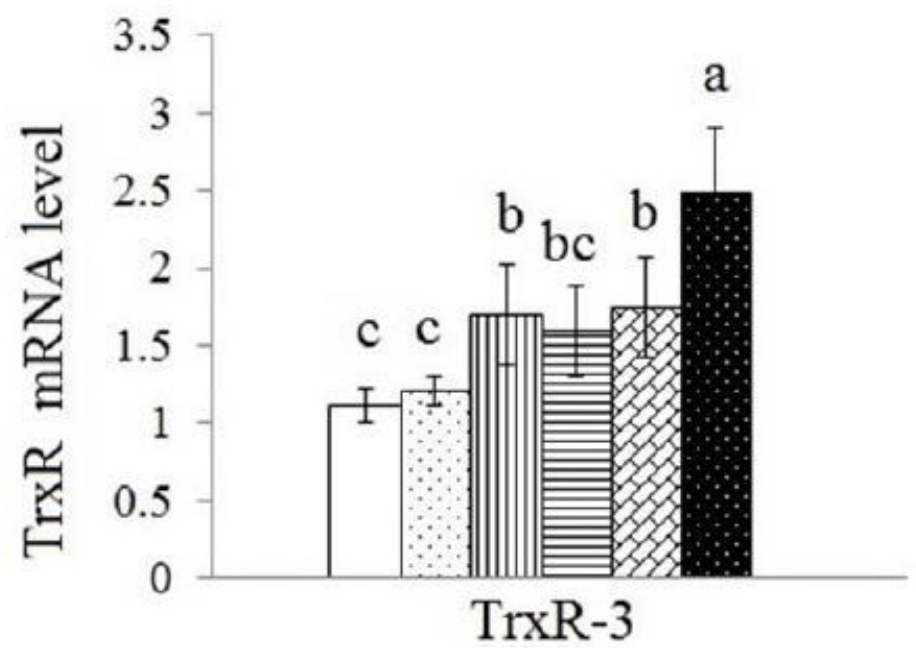

目COS-Se $\quad$ LS-COS $\approx \mathrm{LS}-\mathrm{COS}-\mathrm{Se}$ 


\section{Figure 3}

The level of TrxR-1 and TrxR-3mRNA hepatocyte culture mediumwere shownin basal diet, COS, Na2SeO3, COS-Se, LS-COS and LS-COS-Se in vitro. a:TrxR-1, b: TrxR-3.Control group treated with serum-free medium without $\mathrm{Se}$, sulfate and $\mathrm{COS}$, COS group treated with $\mathrm{COS}$, Na2SeO3group treated with $\mathrm{Na} 2 \mathrm{SeO} 3, \mathrm{COS}-\mathrm{Se}$ group treated with COS-Se, LS-COS group treated with LS-COS, LS-COS-Se group treated with LS-COS-Se. Data are presented as means $\pm S D(n=3)$. a-c: meansin same row with different superscripts significantly differ $(P<0.05)$.
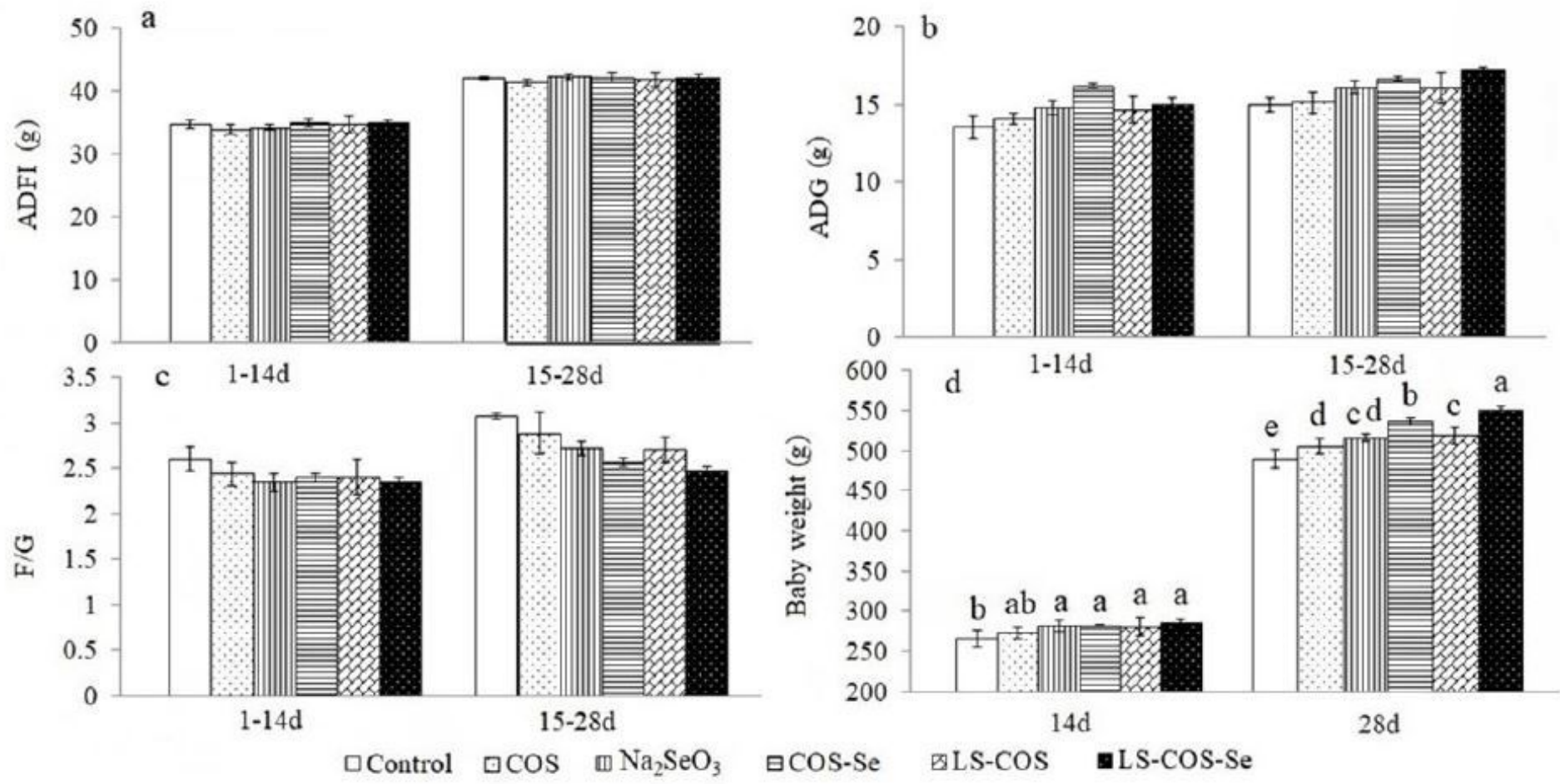

\section{Figure 4}

The growth performance(ADFla,ADGb,F/G $c$ and Baby weight d)of laying hens were shown with basal diet, COS, Na2SeO3, COS-Se, LS-COS and LS-COS-Se in vivo on 14d and 28d.ADFI: average daily feed intake; ADG: average daily weight gain; F/G: ratio of feed to gain; Control group treated withbasal diet, COS group treated with $\mathrm{COS}, \mathrm{Na} 2 \mathrm{SeO} 3$ group treated with $\mathrm{Na} 2 \mathrm{SeO} 3, \mathrm{COS}-\mathrm{Se}$ group treated with COS-Se, LS-COS group treated with LS-COS, LS-COS-Se group treated with LS-COS-Se. Data are presented as means $\pm S D(n=5)$. a-e: meansin same row with different superscripts significantly differ $(P<0.05)$. 

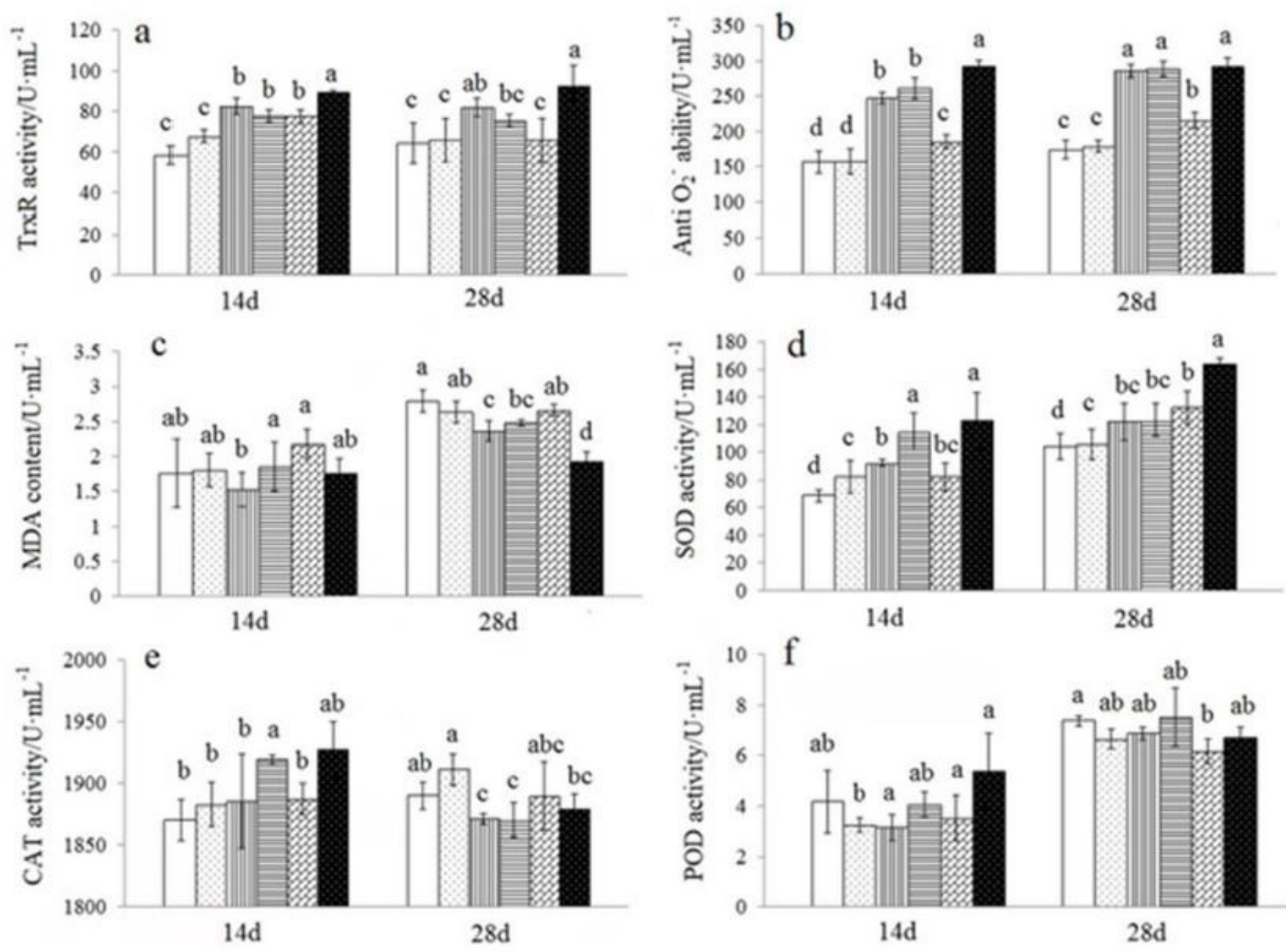

oControl acos $\quad \mathrm{Na}_{2} \mathrm{SeO}_{3}$ acos-Se eLS-COS aLS-COS-Se

\section{Figure 5}

The antioxidant parameters of plasma were shown with basal diet, COS, Na2SeO3, COS-Se, LS-CO Sand LS-COS-Se in vivo on 14d and 28d. a:TrxR, b: AntiO2-, c: MDA, d: SOD, e: CAT, f: POD. Control group treated with basal diet, COS group treated with COS, Na2SeO3group treated with $\mathrm{Na2Se03,} \mathrm{COS-Se} \mathrm{group} \mathrm{treated}$ with COS-Se, LS-COS group treated with LS-COS, LS-COS-Se group treated with LS-COS-Se. Data are presented as means $\pm S D(n=5)$. a-d: means in same row with different superscripts significantly differ $(P<0.05)$. 
a b

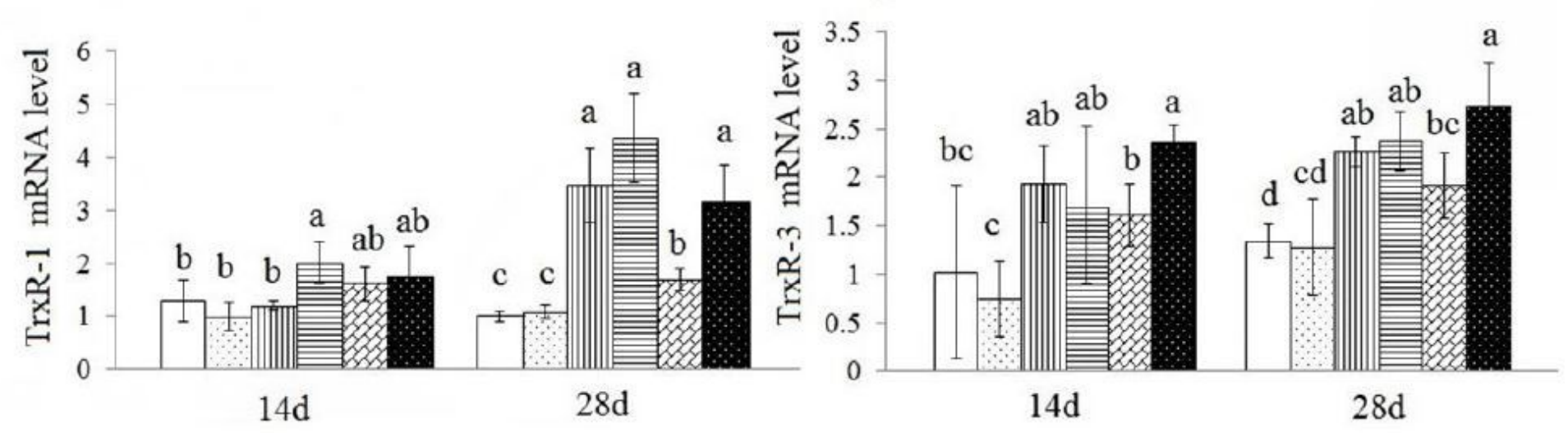

$\square$ Control $\square \mathrm{COS} \square \mathrm{Na}_{2} \mathrm{SeO}_{3}$ 目COS-Se $\quad \mathrm{LS}-\mathrm{COS}$-LS-COS-Se

Figure 6

The level of TrxR-1 and TrxR-3 mRNA of liver tissue were shownin basal diet, COS, Na2SeO3, COS-Se, LSCOS and LS-COS-Sein vivo on 14d and 28d. a:TrxR-1, b: TrxR-3.Control group treated with basal diet, COS group treated with $\mathrm{COS}, \mathrm{Na} 2 \mathrm{SeO}$ group treated with $\mathrm{Na} 2 \mathrm{SeO}$, COS-Se group treated with COS-Se, LSCOS group treated with LS-COS, LS-COS-Se group treated with LS-COS-Se. Data are presented as means $\pm S D(n=5)$. a-c: means in same row with different superscripts significantly differ $(P<0.05)$. 